\title{
Sap collection, Production, Processing and Conservation of Caryota urens (Sulphi) in Bastar (Chhattisgarh)
}

\author{
Chandrashikha Patel* and Sharad Nema \\ School of Studies (Forestry \& Wildlife), Bastar University, Jagdalpur, (CG) India \\ *Corresponding author
}

\section{Keywords}

Caryota urens, Sap, production,

Marketing structure, Bastar

\section{Article Info}

Accepted: 12 December 2020 Available Online: 10 January 2021
Caryota urens is a native rainforest species of tropical Asia. It is known as Sulphi in Bastar region of Chhattisgarh State. It is one of the most common trees which are traditionally tapped for sap from which sweet syrup, sugar, and alcoholic beverages are prepared. The sap of this tree is especially rich with sugar and are highly valued for culinary purposes and religiously valued for brewage purposes in Bastar district of Chhattisgarh. This paper dealt with the tappers' knowledge and management of Sulphi tree, its products, and focus on traditional tapping and processing activities. The ecological and economic importance of Sulphi markets in relation to land configuration and conservation Bastar district are emphasized. The study was conducted on farmers' fields located in Bastar and Lohandiguda block of Jagdalpur, Bastar (Chhattisgarh) to understand the sap collection techniques, quantity and also to explore the possibilities of these potential and popular sap yielding plants for value addition during the year 2017-18. The study revealed that the plant Caryota urens (Sulphi) is one of the important livelihood and socioculturally plants in tribal dominated areas of the Bastar. The sap of this plant is known as nutritionally and medicinally important and popular in the Bastar region of Chhattisgarh State as healthy natural beverage. The sap collection from plant were done either in farmers' field or from naturally available trees and their consumption in local market and in society is very common practices among the tribal culture. The collection and production being associated with tribal's livelihood and revenue generation. In the study middle-aged sulphi trees have been reported to give the best sap yield. Investigation showed that sap yield varied from 12-15,15-20 litter sap/sulphi for 1 day. The Bastar block produces 8939 litter sap from total of 37 Sulphi tree and Lohandiguda block exudes 16361 litter total sap from 46 tree in three months period of study during the study. In the study middle-aged sulphi trees have been reported to give the best sap yield. Investigation showed that sap yield varied from 12-15 and 15-20 litter sap/sulphi for 1 day. It was also recorded that the sap yield peak reaches its maximum before flowering and fruiting during the period of study. This phenomenon of plant utilized for enhancing the sap exudation that may accelerate sap flow in the plant. The tree growth parameters such as tree height, diameter, tree age, diameter, basal area were also recorded and compared with sap yield. The least damages and limited tapping for harvesting sap of Sulphi tree plants are suggested for domestic utilization as a fresh beverage and sale in local markets. 


\section{Introduction}

A strong possibility exists that traditionally claimed health benefits of the Caryota urens sap such as anti-hyperglycemic etc., are mediated largely via antioxidant effects Caryota urens family: Arecaceae, is underutilized palm species mainly distributed in several countries in south Asia: India Sri Lanka, Malaysia and Indonesia to Philippines (Dalibard, 1999). This palm has several synonyms such as fish tail palm, toddy palm, jiggery palm and popular as kittul in Sri Lanka, traditionally young inflorescence of Caryota urens palm is tapped for its sweet phloem sap which is then used to produce sweeteners and fermented beverage. To folkloric knowledge, Caryota urens sap and sap based products posses health promoting properties. However, as yet these functional also to the best of our knowledge, there are no reports available on antioxidant activity of any palm sap.

Traditional sources of sweetenecle jiggery are produced in farms. In arid areas treacle and jiggery are produced from Palmyra in the coastal zone from Coconut palms and in the wet interior and highland regions from fishtail palms. Thus sugar can be locally produced from one or another palm on most parts of land. The fishtail palm or as it is locally known in Sinhalese, is a very common tree in the lowland rain forest and in mixed species forest gardens managed in highland Sri Lanka. This palm yields a rich dark syrup with a highly valued, distinctive taste. In comparative testing of raw sugar repotted from the Fairchild botanical gardens in Florida, kitul jiggery ranked among those of highest quality (Lotschert 1985). It's export potential is being tested with success in the Australian consumer market.

Caryota urens is popularly known as shankarjata in ayurveda is distributed more or less throughout sub Himalaya tract from Nepal eastwards, very common in Ghats and sub Montana forests of Mysore, in Malabar coast, Konkani, Cochin and Travancore. Also in tropical Asia Malaya, Singapore, Australia and Ceylon. Leaf is reported to cure hemicranias and root of the plant is reported for treatment of abortion, dysentery and tooth cavity to prevent decay. Literature revealed that pharmacognostic studies have not been reported for the leaf of this plant. Therefore the main aim of the present work is to study the macro, microscopic and some other pharmacognostic characters and physicochemical standards of leaf of Caryota urens which could be used be explore this plant. Caryota urens is an underutilized palm species which is native to low land forests of tropical Asia including India, Malaysia and Indonesia and is popular as kithul in sri Lanka. jiggery, treacle and toddy are produced from sap of the young inflorescence of stems for building materials and healthy food from starch which is extracted from the pith of the stem.

The Caryota urens (sulfi) is among the most popular plants in tribal dominate area of the state i.e. Bastar. it is one of the most important plant in the tribal society from the utility point of view in the form liquor and as medicine too it is also one of the preferred plant in the formers filed for livelihood and socio-economic stoles point of view in the society hones the present work looking is use value of plant in the area need to see documentation their production, market potentials and its income of tribes.

The Caryota urens (sulphi) is among the most popular plants in tribal dominate area of the state i.e. Bastar. it is one of the most important plant in the tribal society from the utility point of view in the form of liquor and as medicine too it is also one of the preferred plant in the formers filed for livelihood and 
socio-economic stoles point of view in the society hones the present work looking is use value of plant in the area need to see documentation their Production, market potentials and its income of tribes.

\section{Sap harvesting}

It was revealed that tapping of the Caryota urens for sap production started from October and continued to mid June for approximately 273 days in the winter season. In the 273 days, palm is tapped in every day morning and evening sap production. Palms aged 3032 years growing in the field and in the axils produced the most sap.

\section{Sap harvesting timming}

Sap is harvested 2 times in 1 day: - Morning and Evening.

\section{Materials and Methods}

\section{Study site}

The present work was carried out in the 2 block villages of Bastar and Lohandiguda block of Bastar district, Chhattisgarh. This area is very significant for plant/trees studies showing to the dominance of different tribal communities, like Muriya, Bhatra,Gond etc. The extensive studies were conducted with the help of tribal people and village medicine men of the area and information gathered local name, used plant part and medicinal importance of plant plant were collected from the fields, given noted by the information on plant part used (leaf) and local uses were recorded on the labels. This information collected was verified by cross -checking with tribal living medicine, personal contact and keen observation.

Bastar and Lohandiguda of an important local market place for forest production. Tribal living in nearby Jagdalpur and village bring forest products like sulphi (used for Bastar beer) Tribal's sell these things to local vendors. These markets are not only place for selling and buying forest products but also for fruits, local beer, clothes, fish and meat, green vegetable. Most of the vegetables sold in the market are locally grown.

\section{About lohandiguda block}

Lohandiguda is a block positioned in Bastar district in Chhattisgarh. Positioned in rural part of Chhattisgarh, it is one of the 7 blocks of Bastar district. According to the administration register, the block number of Lohandiguda is 127 . The block has 85 villages and there are total 17005 families in this block.

\section{Geographical location}

Bastar district is situated in south eastern part of the state of Chhattisgarh in India. the district is surrounded by district Kondagaon in north, district Bijapur and Dantewada in west and district Sukma in south and in east and south east by Koraput district of neighboring Odisha state. It falls in Survey of India; topo sheet Nos. 65 E, F, I and bounded between $1840^{\prime}$ to $1935^{\prime}$ North latitude and 8120 ' to $8215^{\prime}$ 'East longitudes.

\section{Climate}

There are three main climatic seasons as summer, winter and rainy. The winter season at the beginning of November and lasts till middle of February. The summer season start from of February to May and June to October is the rainy season. July is the peak rainfall month in the district. the climate of the area is tropical sub humid with mean annual air temperature of $27.00 \mathrm{c}$ and moan annual rainfall of $1534 \mathrm{~mm}$. the estimated mean annual soil temperature (MAST) is $26{ }^{0} \mathrm{C}$ and 
means soil summer temperature is $29.30^{0}$ C.The temperature regime is isohyperhermic whereas moisture regimes are udic and ustic.

\section{Geology}

The region belong to older arch an of peninsular region which has remained stable for long time and has kept its geology antiquity in spite of various phases of diastrophic movement occurred in the area. The southern and northern portions of the district are dominated by the foliated section of schistose and gneisses of arch man era. In northern and eastern portions the disintegrated granitoids predominate. Towards eastern ghat section of the district; numerous lenses of charnockites are noticed in gneissic formations.

\section{Soils}

Literates and lateritic soil cover a large area of the district. In some areas red and yellow soils also occur in patches. In abujhmar tract the trap rocks occur over the slopes have thin light soil. Whereas, fresh alluvia soil is found in the beds of steams and rivers Indrāvati, Godavari and Mahanadi. The Texture of the soil varies from sandy to fine textured clayed soil. PH of the soil varies 4.5 to 6.5 in Sal forest and 5.5 to 7.8 in Teak forests, while miscellaneous forests have generally mid values, thus the soil is slightly basic to slightly acidic and capable of supporting both Sal and teak forests. In spite of the frequent summer fires the percentage the organic matter in the top layer of the soil generally quiet, varying from 0.5 to $2.5 \%$

\section{Ethnic Groups in the study areas}

There are mainly two dominated tribes namely Gond and Halba are living in and around Bastar district, Chhattisgarh.

\section{Experimental details}

\section{Method}

The filed survey was carried out in the forest village of the Bastar and Lohandiguda block of Bastar district.

The methodology is following as under

1) Field survey

2) Literature collection

The main aim of the surrey was to collect information about the wild palm plant/tree which are used by the tribal's and also spices are identified and documental by collecting sample of sulphi species.

Literature collection: During the study on livelihood of sulphi sap used by the tribal people in Bastar and Lohandiguda block. The information regarding sulphi sap used by tribal peoples and their livelihoods, economy condition and income from sulphi eat were collected from the literatures, government organization and local weekly markets etc.

\section{Results and Discussion}

Tapping is a technique that is used to collect sap from sulphi sap. According to Johnson tapping has a long history and is a pan tropical activity. This practice is believed to have originated roughly 40 years ago in india sap extraction is very common and is technically advanced in Asia and the pacific islands. in Africa, simpler tapping practices are used on Elaeis guineensis, Hyphened spp.,in contrast, it is an uncommon activity in Latin America.

Tapping operation was observed to be stared the entire onset at the onset of winter by series of pruning usually 2 times. Sap production of morning and evening daily 15-20 liter par 
day. The tappers skill lies in maximizing the sap flow to the inflorescence while retarding flower extension. when a palm is about to flower, the inflorescence becomes visible in the tree top. About two month after a young inflorescence first emerges; the tapper climbs the palm and carefully removes the outer layers of the sheath or spathe protecting the flowers. As discussed below, tapping activities are typically carried out men. The tapper ties a forked stick into place under the inflorescence to replace the spate's supportive function. Tappers say that the number of layers indicates the number of individual flowers to come from the inflorescence, ranging from one to twelve. The tapper makes a roughly $15 \mathrm{~cm}$ long, $5 \mathrm{~cm}$ wide, and $2 \mathrm{~cm}$ deep incision in the side of the flower. Tapper apply a special "medicine" in this cut to stimulate sap flow. Generally sap is collected from one side of the sulphi sap in one season and the successive season sap must be collated from the upper opposite side of the previous cut.

\section{Number of tree age}

The chapter deals with the finding of data on sulphi (Caryota urens) Sap production, sulphi sap production and income in the selected 2 block on Bastar district of Chhattisgarh. The data is number of tree in Bastar and Lohandiguda block. Total 37 tree Bastar block sap production and 46 tree in Lohandiguda block sap production. table (1) represents number of tree with age details.

\section{Methods for tapping sulphi sap}

Tapping is a technique that is used to collect sap from sulphi sap. According to Johnson tapping has a long history and is a pan tropical activity. This practice is believed to have originated roughly 40 years ago in india.sap extraction is very common and is technically advanced in Asia and the pacific islands. in Africa, simpler tapping practices are used on E.guineensis, hyphened spp.,in contrast, it is an uncommon activity in Latin America.

Tapping methods for Sulphi- Sulphi spices are tapped differently in different countries. In different counties. In general, tapping methods are classified as destructive or non destructive. Destructive tapping triggers the death of the tapped palm, whereas the palm can survive when non-destructive tapping methods are used. Depending on the type of palm and the common local practice, tapping can be applied to various parts of the palm, such as the stem, the stalk or the inflorescence (a spadix surrounded by a spathe)

\section{Tapping time}

Sap yield can reach a maximum just before flowering and fruiting pethiyagoda suggested that a rapid increase in respiratory rate occurs during this period. This phenomenon may accelerate conversions of resaves into nutrients and the transfer rate of sap flow to growing points.

\section{Age of tree}

Middle -aged sulphi trees have been reported to give the best sap yield as evidenced from A. showed that sap yield varied for 12-15,1520 and 30 year old date salphi to be $12-15,15-$ 20 litter sap/sulphi for 1 day.

\section{Quantity of sulphi (Caryota urens) Production}

The data on provide the sulphi quantity, production and income on the Bastar and lohandiguda block. The data were tabulated and production of Per tree litter in Table (1) and (2)for Bastar and lohandiguda block village in Bastar district of C.G respectively. The perusal of data revealed that the total 37 
tree of sulphi in Bastar block and production 8939 liter sap maximum sap production in ghatpadmo villege 623 liter sap production 3 month data and minimum sap production tree in kalipur and kumrawand villeges 78 liter sap production of Bastar block. Lohandiguda block 46 tree of salphi in production 16361 liter sap. Maximum sap production 666 litter in Lohandiguda villege of 3 month data and minimum sap production tree in kotwaar para villege 115 litter sap in Lohandiguda block.

Table.1 Study of Caryota urens tree sap production in litter and cost of production in Bastar Block Jagdalpur C.G

\begin{tabular}{|c|c|c|c|c|c|c|}
\hline S.N. & Tree in year & Age in tree & Village & $\begin{array}{c}\text { Sap of } \\
\text { production in } \\
\text { letter }\end{array}$ & $\begin{array}{c}\text { Rs of sap in per } \\
\text { litter }\end{array}$ & Total income in Rupees \\
\hline \multirow[t]{5}{*}{1} & 5-10 Year & 6 & Guchaguda & - & 40 & - \\
\hline & & 8 & Kalipuir & - & 40 & - \\
\hline & & 8 & Kalipuir & - & 40 & - \\
\hline & & 9 & Guchaguda & - & 40 & - \\
\hline & & 9 & Guchaguda & - & 40 & - \\
\hline \multirow[t]{3}{*}{2} & 11-15 Year & 15 & Kumrawand & 152 & 40 & 6080 \\
\hline & & 15 & Kumrawand & 98 & 40 & 3920 \\
\hline & & 15 & Kalipuir & 85 & 40 & 3400 \\
\hline \multirow[t]{16}{*}{3} & 16-20 Year & 18 & Ghatlohga & 218 & 40 & 8720 \\
\hline & & 18 & Kalipur & 525 & 40 & 21000 \\
\hline & & 18 & Kumrawand & 86 & 40 & 3440 \\
\hline & & 18 & Ghatlohga & 225 & 40 & 9000 \\
\hline & & 18 & Bastar & 403 & 40 & 16120 \\
\hline & & 18 & Bastar & 304 & 40 & 12160 \\
\hline & & 20 & Bastar & 302 & 40 & 12080 \\
\hline & & 20 & Ghatpadmo & 220 & 40 & 8800 \\
\hline & & 20 & Kumrawand & 102 & 40 & 3400 \\
\hline & & 20 & Kalipuir & 78 & 40 & 3120 \\
\hline & & 20 & Ghatpadmo & 623 & 40 & 24920 \\
\hline & & 20 & Kumrawand & 102 & 40 & 3400 \\
\hline & & 20 & Aadawal & 505 & 40 & 20200 \\
\hline & & 20 & Bastar & 305 & 40 & 12200 \\
\hline & & 20 & Aadawal & 112 & 40 & 4480 \\
\hline & & 20 & Ghatpadmo & 218 & 40 & 8720 \\
\hline \multirow[t]{12}{*}{4} & 21-25 Year & 21 & Guchaguda & 600 & 40 & 24820 \\
\hline & & 21 & Kumrawand & 78 & 40 & 3120 \\
\hline & & 21 & Ghatpadmo & 218 & 40 & 8720 \\
\hline & & 22 & Kudalgaon & 608 & 40 & 24820 \\
\hline & & 22 & Guchaguda & 503 & 40 & 20120 \\
\hline & & 25 & Kangoli & 504 & 40 & 20160 \\
\hline & & 25 & Kumrawand & 102 & 40 & 4080 \\
\hline & & 25 & Kumrawand & 108 & 40 & 4320 \\
\hline & & 25 & Kumrawand & 175 & 40 & 7000 \\
\hline & & 25 & Kalipur & 415 & 40 & 16600 \\
\hline & & 25 & Bastar & 285 & 40 & 11400 \\
\hline & & 25 & Ghatpadmo & 504 & 40 & 20160 \\
\hline \multirow[t]{3}{*}{5} & 26-30 Year & 26 & Kudalgaon & 176 & 40 & 7040 \\
\hline & & & Total & 8930 & & 357520 \\
\hline & & & MEAN AVERAGE & 241.59 (L.) & & 9662.7 Rupees \\
\hline
\end{tabular}


Table.2 Study of Caryota urens tree sap production in litter and cost of production in Lohandiguda Block Jagdalpur C.G

\begin{tabular}{|c|c|c|c|c|c|c|}
\hline S.N. & Tree in year & Age in tree & Village & $\begin{array}{c}\text { Sap of } \\
\text { production in } \\
\text { letter }\end{array}$ & $\begin{array}{c}\text { Rs of sap in } \\
\text { per litter }\end{array}$ & Total income in Rupees \\
\hline \multirow[t]{5}{*}{1.} & 5-10 Year & 7 & Lohandiguda & - & 40 & - \\
\hline & & 8 & Lohandiguda & - & 40 & - \\
\hline & & 9 & Lohandiguda & - & 40 & - \\
\hline & & 9 & Lohandiguda & - & 40 & - \\
\hline & & 10 & Kotawarpara & - & 40 & - \\
\hline \multirow[t]{10}{*}{2} & 11-15 Year & 12 & Kotawarpara & - & 40 & - \\
\hline & & 12 & Kurushpal & 403 & 40 & 16120 \\
\hline & & 13 & Sargudu & 428 & 40 & 17120 \\
\hline & & 13 & Gunpur & 218 & 40 & 8720 \\
\hline & & 15 & Sargudu & 248 & 40 & 9920 \\
\hline & & 15 & Kurushpal & 220 & 40 & 8800 \\
\hline & & 15 & Gunpur & 415 & 40 & 16600 \\
\hline & & 15 & Gotiya & 525 & 40 & 21000 \\
\hline & & 15 & Gotiya & 538 & 40 & 21520 \\
\hline & & 15 & Bheshgaon & 479 & 40 & 19160 \\
\hline \multirow[t]{28}{*}{3} & 16-20 Year & 16 & Badedharur & 152 & 40 & 6080 \\
\hline & & 16 & Patelpara & 523 & 40 & 20920 \\
\hline & & 16 & Kotawarpara & 525 & 40 & 21000 \\
\hline & & 16 & kurushpaal & 503 & 40 & 20120 \\
\hline & & 16 & Naranpaal & 623 & 40 & 24920 \\
\hline & & 16 & Temra & 525 & 40 & 21000 \\
\hline & & 17 & Lohandiguda & 504 & 40 & 20160 \\
\hline & & 17 & Kotawarpara & 600 & 40 & 24000 \\
\hline & & 17 & Usribeda & 333 & 40 & 13320 \\
\hline & & 17 & Bheshgaon & 449 & 40 & 17960 \\
\hline & & 18 & Lohandiguda & 248 & 40 & 9920 \\
\hline & & 18 & Badedharur & 623 & 40 & 24920 \\
\hline & & 18 & Lohandiguda & 325 & 40 & 13000 \\
\hline & & 18 & Sargiguda & 425 & 40 & 17000 \\
\hline & & 18 & Ghotiya & 512 & 40 & 20480 \\
\hline & & 18 & Ganpur & 428 & 40 & 17120 \\
\hline & & 18 & Lohandiguda & 403 & 40 & 16120 \\
\hline & & 18 & Naranpaal & 503 & 40 & 20120 \\
\hline & & 18 & Lohandiguda & 666 & 40 & 26640 \\
\hline & & 19 & Lohandiguda & 415 & 40 & 16600 \\
\hline & & 20 & Lohandiguda & 225 & 40 & 9000 \\
\hline & & 20 & Lohandiguda & 218 & 40 & 8720 \\
\hline & & 20 & Koatwarpara & 225 & 40 & 9000 \\
\hline & & 20 & Koatwarpara & 523 & 40 & 20920 \\
\hline & & 20 & Lohandiguda & 503 & 40 & 20120 \\
\hline & & 20 & Usribeda & 215 & 40 & 8600 \\
\hline & & 20 & Temra & 403 & 40 & 16120 \\
\hline & & 20 & Temra & 305 & 40 & 12200 \\
\hline \multirow[t]{5}{*}{4} & 21-25 Year & 21 & Temra & 415 & 40 & 16600 \\
\hline & & 22 & Kotawarpara & 115 & 40 & 4600 \\
\hline & & 25 & Usribeda & 455 & 40 & 18200 \\
\hline & & & Total & 16361 & & 654440 \\
\hline & & & $\begin{array}{c}\text { MEAN } \\
\text { AVERAGE }\end{array}$ & 355.67 (L) & & 14226.95(Rupees) \\
\hline
\end{tabular}


Fig.1 Distribution of respondents to the their sap production of Caryota urens in two block under farmers filed at Jagdalpur

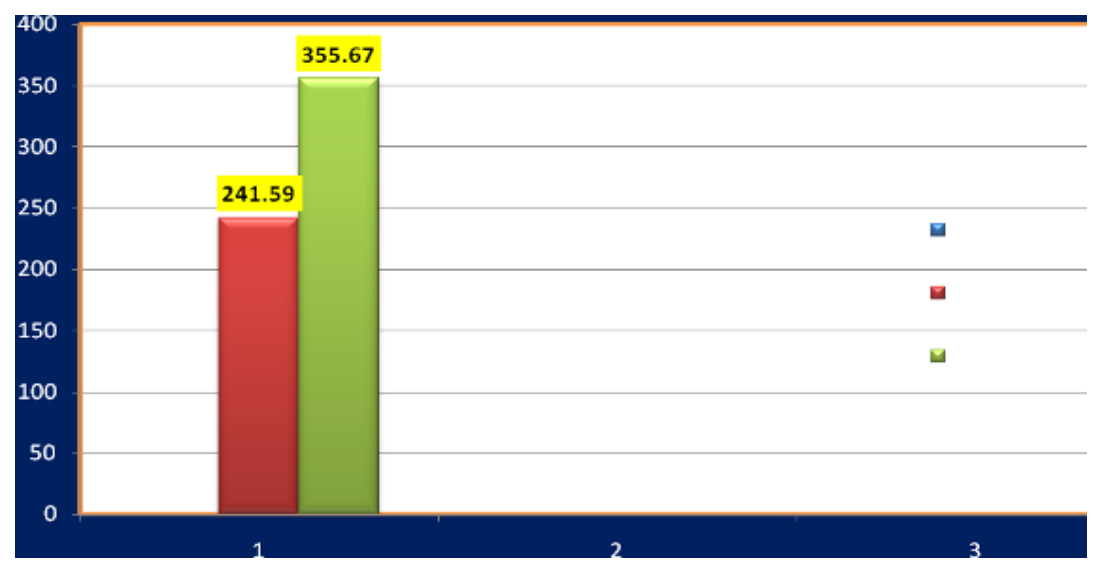

Fig.2 Distribution of respondents to the their income from sap production of Caryota urens in two block under farmers filed at jagdalpur

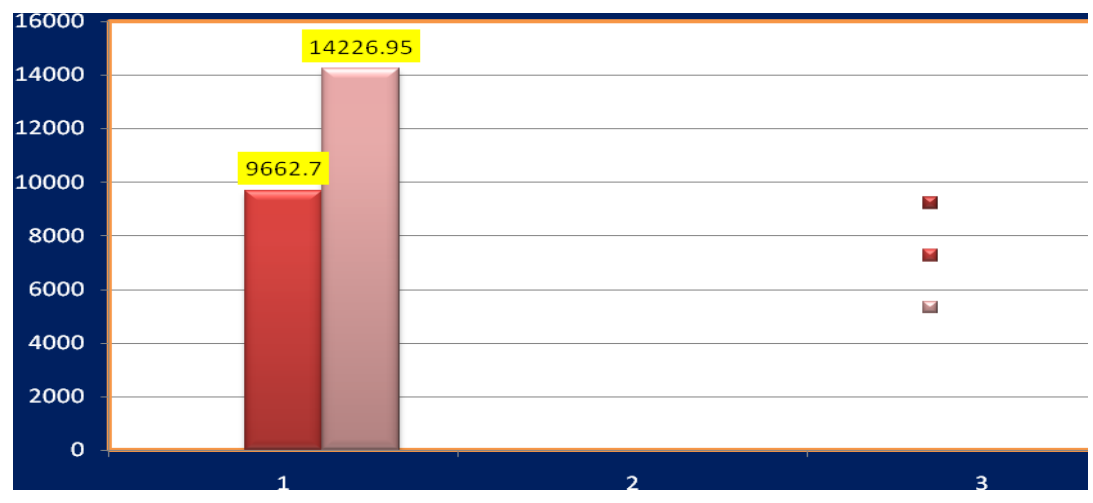

Sulphi production of bastar block
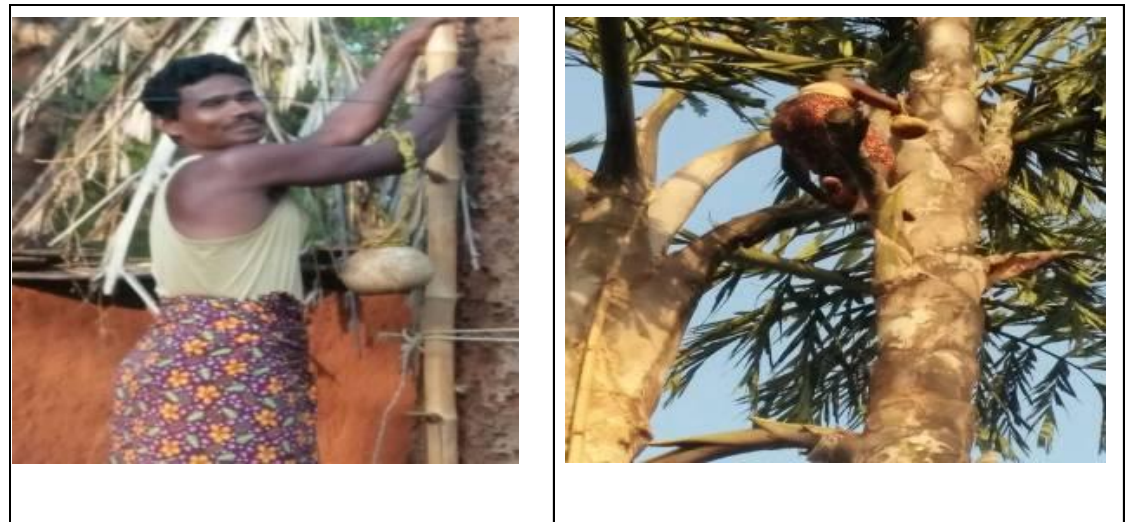
Sulphi production of Lohandiguda block in baster

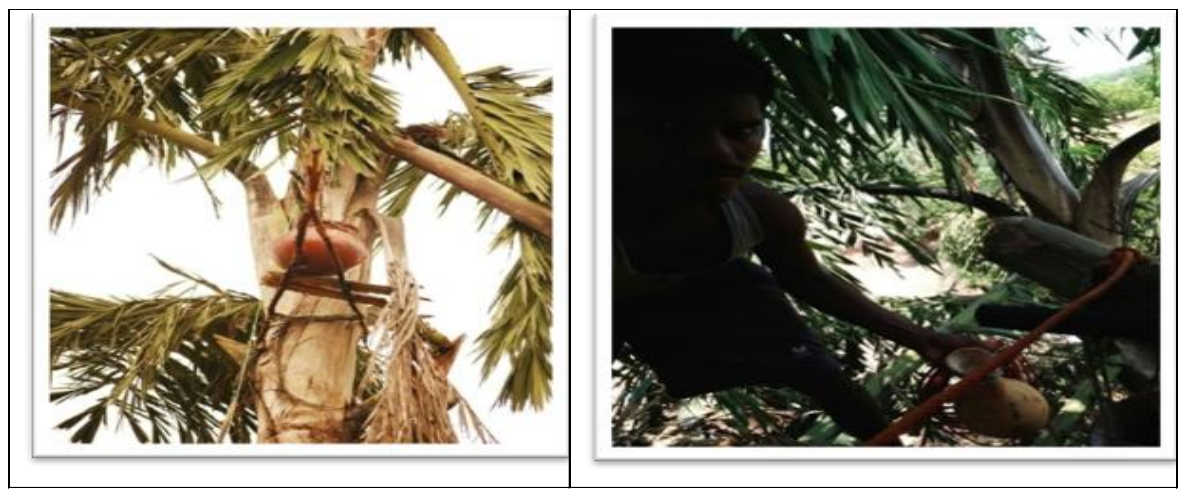

Local market visit Bastar \& Lohandiguda block

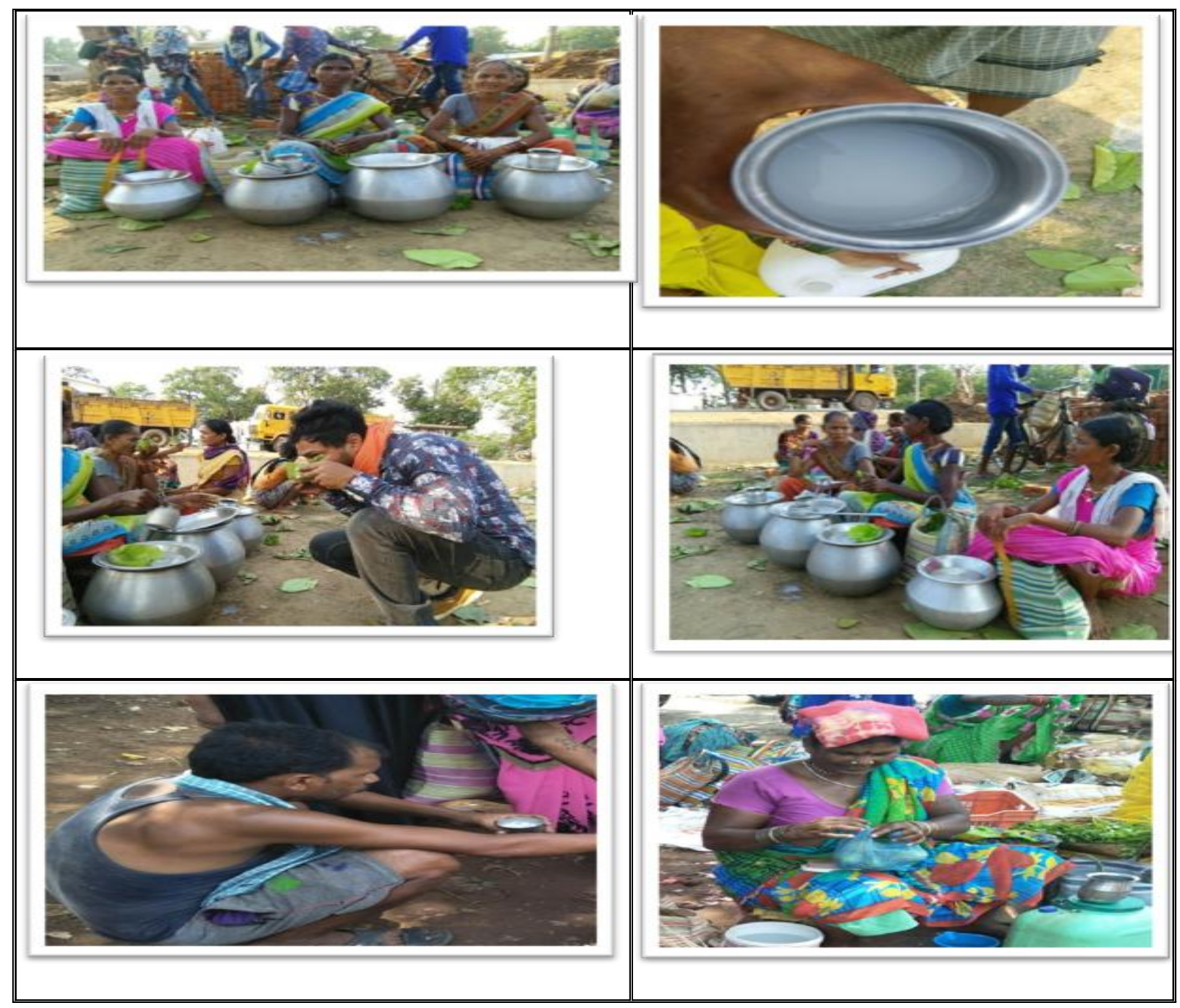




\section{Morning \& Evening sap collection}

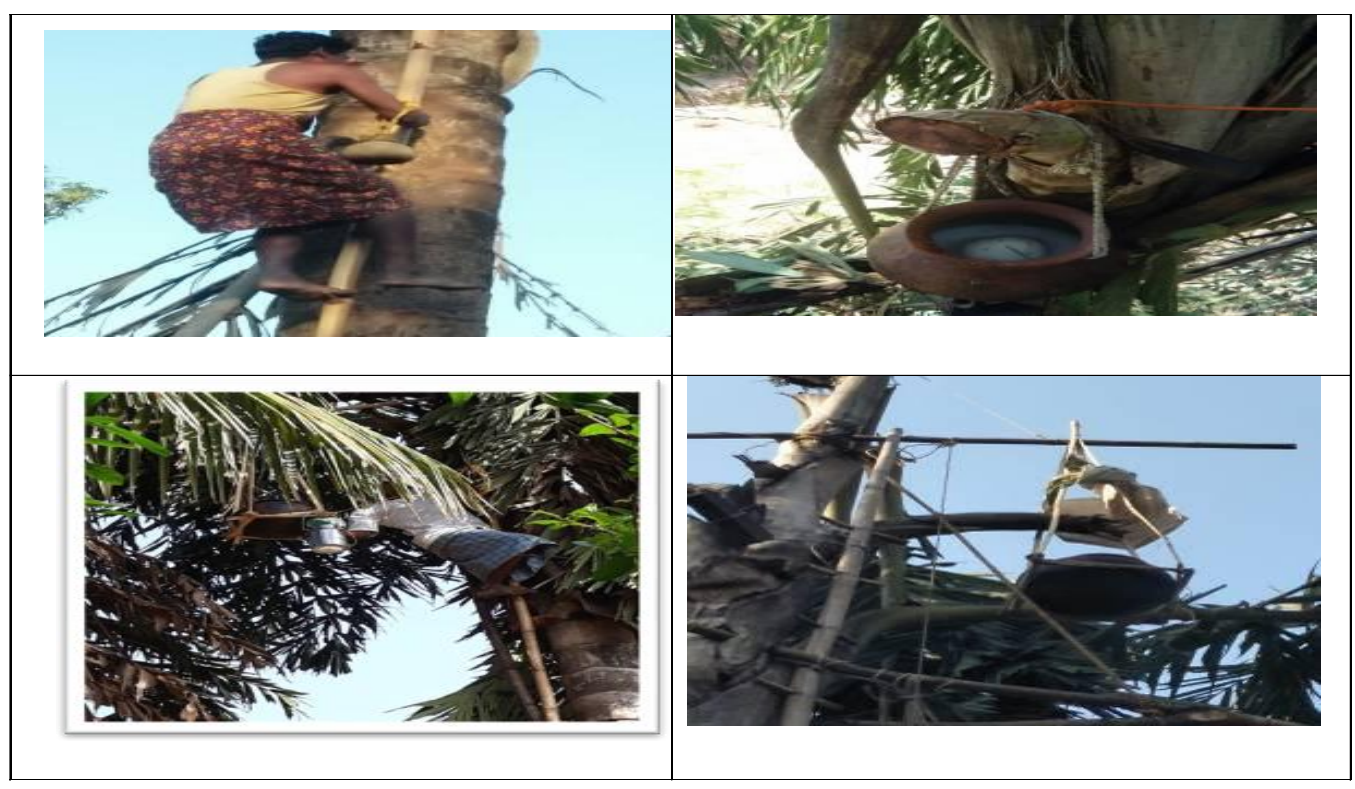

\section{Caryota urens cost of production}

The data on provide the sulphi (Caryota urens) on income by farmers were tabulated an cost in rupees in table (1) the data showed that the maximum income Rs.24920/- of sulphi sap in Ghatpadmovillege and minimum income by Rs 3120/- in kalipurand kumrawand villeges and total income of Rs 357520 /-in Bastar block.

The data on provide the sulphi (Caryota urens) on income by farmers were tabulated a cost in rupees in table (2) the data showed that the maximum income Rs. 26640/- of salphi in Lohandiguda villege and minimum income by Rs 4600 /- in kotawaar para villege and total income of Rs 654440 /- in Lohandiguda block.

Wimalasiri et al., (2015) starch from pith of Caryota urens (Family:Arecaceae) palm is known as "kittul flour" and is claimed to have health benefits to folklore and ayurveda. Antioxidants are believed to possess numerous health benefits however, as yet, health of C.urens flour have not been scientifically investigated. antioxidant properties of Caryota urens flour were tested using different in vitro assays namely, 2,2azino-bis 3-ethylbenzothiazoline-6-sulfonic acid, ferric reducing antioxidant power, oxygen radical absorbance capacity and ferrous ion chelating assays. total phenolic content (TPC) and total Flavonoid content (TFC) were also evaluated. Anti-diabetic properties were estimated using alpha amylase and alpha glucosidase enzyme inhibition assays. dried metabolic extracts of both boiled and raw samples were used in all assays.

Berkeley (1995) reported distribution Caryota Urens, known as the kitul in Sri Lanka, is a native rainforest species of tropical Asia. It is also one of the most common tree in the perennial forest gardens of highland Sri Lanka. kitul is traditionally tapped. the syrup and sugar have a special richness and are highly valued for culinary purposes in Sri Lanka.

Patel et al., (2016) reported the increasing interest in powerful biological activity of 
secondary metabolites outlined the necessity of determining their contents in medicinal plants. The present study intended to find out the active constituents. Caryota urens plant is rarely mentioned in published books and there is no date of showing which constituents are present in this plant qualitative chemical examination of various successive extracts of leaves of Caryota urens showed presence of phytosterols, triterpenods, flavanoids, tannins and phenolic compounds and carbohydrates were present.

Uddin et al., (2015) reported Complementary and alternative medicine based on plants is the worlds oldest from of medicine and recent report suggest that such therapies still enjoy vast popularity, especially in developing countries where most of the population dose not have easy access to modern medicine.

\section{Acknowledgement}

The authors express their deep sense of gratitude to DRS, Bastar Universiy, Jagdalpur (CG), Dean, Bastar Universiy, Jagdalpur and Head of Forestry Department for providing the opportunity to study and other Department. I extend my gratitude to $\mathrm{CCF}$, $\mathrm{CF}$, DFO, Range officers and villagers of Bastar district in Chhattisgarh for their rendered support to identify the species and guidance to move in forest during course of study in Bastar and Lohandiguda Block, without their support we could not be able to commence the work smoothly.

\section{References}

Berkeley (1995). The Kitul Palm: Ethnobotany of Caryota urens L.In Highland Sri Lanka. Journal of Ethnobiology. 15(2):161-176.

Dalibard, C. (1999). Overall view on the tradition of tapping palm trees and prospects for animal production,
International Relations Service, Ministry of Agriculture, Paris, France. (11): 181-182.

Patel, R., Mariyan, P., Hiteksha S. and Saluja, A. k. (2016). Identification of terpenoids and steroidal compounds in Caryota urens leaves by column chromatography and various spectroscopic techniques. indubhai Patel college of pharmacy and research centre, dharmaj, Gujarat, India. (5): 1610-1622

Ranasinghe, P., Premakumaara,G.A.S., Wijayarathna, C.D. and Ratanasooriya, W.D. (2012). Antioxidant activity of Caryota urens L.(Kithul) sap. Faculty of science university of Colombo, Colombo Sri Lanka, 23(2):117-125.

Lotschert, W. (1985). Palmen. Eugen Ulmer Verlag, Stuttgart.

Uddin, Md. S., Hasan, Md. F., Mamun, Al. A., Hossain Md.S., Islam, Md. T., and Md. Asaduzzaman (2015). In vitro estimation of antioxidant activity of Caryota urens fruits. Department of pharmacy, southeast university, Dhaka, Banglasdesh. 2(11):1486-1490.

Vaishnavi, R. and Suneetha,V. (2013). Phytochemical analysis on Caryota urens (fishtail palm) fruit from VIT university campus for pharmaceutical use, school of bio science and technology, VIT university, Vellore, India. (3):71-75.

Wijesinghe, JAAC, Wicramasinghe, I. and saranandha, K.H. (2016). Kithul flour (Caryota urens) as a potential flour source for food industry. Department of food science \& techonology, university of Sri Jayewardenpura, Sri Lanka food research unit gannoruwa.vol. (3)1: 1018.

Wijesinghe, JAAC., Wicramasinghe, I. and Saranandha, K.H. (2015). Deviation of chemical properties of kithul (Caryota urens) flour obtained from five 
different growing areas in Sri Lanka, Department of food science and technology, faculty of applied sciences, university of Sri Jayewardenepura, gangodawila, Nugegoda, Sri Lanka food research unit, Gannoruwa. (2): 2349-6002

Wimalasiria,G.E.M.,Ranasingheb,p.,Gunaratn ec, D.M.A. and Arachchia vidhana L.P. (2015). Antioxidant and anti-diabetic properties of Caryota urens (kithul) flour, international conference of sabaragamuwa university of Sri Lanka,procedia food science 6(016):181-185.

\section{How to cite this article:}

Chandrashikha Pateland Sharad Nema. 2021. Sap collection, Production, Processing and Conservation of Caryota urens (Sulphi) in Bastar (Chhattisgarh). Int.J.Curr.Microbiol.App.Sci. 10(01): 1556-1567. doi: https://doi.org/10.20546/ijcmas.2021.1001.182 